\title{
Periphytic algae in a floodplain lake and river under low water conditions
}

\author{
Andressa Bichoff ${ }^{1,2}$, Nicolli Cristina Osório ${ }^{I}$, Bárbara Dunck ${ }^{I}$, Liliana Rodrigues ${ }^{I}$ \\ 'Programa de Pós - Graduação de Ambientes Aquáticos Continentais (PEA), Universidade Estadual \\ de Maringá, Paraná, Brazil. \\ ${ }^{2}$ Corresponding author: Andressa Bichoff, e-mail: andressabichoff@hotmail.com
}

\begin{abstract}
BICHOFF, A., OSÓRIO, N.C., DUNCK, B., RODRIGUES, L. Periphytic algae in a floodplain lake and river under low water conditions. Biota Neotropica. 16(3): e20160159. http://dx.doi.org/10.1590/1676-0611-BN-2016-0159
\end{abstract}

\begin{abstract}
Drought events will become more frequent due the climate change. In floodplains, periphytic algae are responsible for part of the primary production, are the principal source of organic carbon deposition, play an important role in mineralization and nutrient cycling, and are the base of the food web for many organisms. As algae distribution in aquatic environments is a strong indicator of physical and chemical conditions of the sites, we aimed to determine the structure of periphytic algae in lentic and lotic environments during drought conditions and to uncover the main local abiotic factors in community structuring. We hypothesized diatoms would be more frequent than green algae and desmids at both sites, due to their resistance characteristics, and that higher periphyton algal richness, density and diversity would occur in the lake due to the greater availability of nutrients and the absence of flow. The study was carried out in the Finado Raimundo lake and the Ivinhema river in the Upper Paraná river floodplain during the low water period of 2011. Petioles of the aquatic macrophyte Eichhornia azurea (Sw.) Kunth were used as a substrate for periphytic algae. We found a total of 171 species, 104 species in the lake and 80 in the river. Diatoms were predominant at both sites due to their strategic traits, and between sites, there were different patterns in the periphytic algal community structure, owing to the distinctive physical and chemical characteristics of the lake and the river. Achnanthidium minutissimum (Kützing) Czarnecki and Nitzschia palea (Kützing) W. Smith were the most abundant species in both environments. Our results showed patterns of periphytic algae in a floodplain during drought conditions, which will assist in understanding their structuring during future drought scenarios.
\end{abstract}

Keywords: diatoms, flood pulse, freshwater, drought events.

BICHOFF, A., OSÓRIO, N.C., DUNCK, B., RODRIGUES, L. Algas perifíticas em lago e rio de planície de inundação sob condições de águas baixas. Biota Neotropica. 16(3): e20160159. http://dx.doi.org/10.1590/16760611-BN-2016-0159

Resumo: Eventos de seca serão mais frequentes, devido as mudanças climáticas. Em planícies de inundação, as algas perifíticas são responsáveis por parte da produção primária, são a principal fonte de deposição de carbono orgânico, desempenham um papel importante na mineralização e ciclagem de nutrientes, e são a base da cadeia alimentar de muitos organismos. Considerando que a distribuição de algas nos ambientes aquáticos é uma forte indicadora das condições físicas e químicas dos locais, objetivamos determinar a estrutura de algas perifíticas em ambientes lênticos e lóticos em condições de seca e de descobrir os principais fatores abióticos locais na estruturação da comunidade. Nossa hipótese é que as diatomáceas seriam mais frequentes do que as algas verdes e desmídias em ambos os locais, devido as suas características de resistência, e que a maior riqueza, densidade e diversidade de algas perifíticas que ocorreria no lago devido à maior disponibilidade de nutrientes e a ausência de fluxo. O estudo foi realizado no lago Finado Raimundo e rio Ivinhema na planície de inundação do alto rio Paraná, durante o período de águas baixas de 2011. Pecíolos das macrófitas aquáticas Eichhornia azurea (Sw.) Kunth foram utilizados como substrato para algas perifíticas. As diatomáceas foram predominantes em ambos os locais, devido às suas características estratégicas, e entre os locais, houve padrões diferentes na estrutura da comunidade de algas perifíticas, devido as características físicas e químicas distintas do lago e do rio. Achnanthidium minutissimum (Kützing) Czarnecki e Nitzschia palea (Kützing) W. Smith foram as espécies mais abundantes em ambos os ambientes. Nossos resultados mostraram padrões de algas perifíticas em uma planície de inundação em condições de seca, o que vai ajudar na compreensão de sua estruturação em futuros cenários de secas.

Palavras-chave: diatomáceas, pulso de inundação, água doce, eventos de seca. 


\section{Introduction}

Floodplains are among the most productive ecosystems on the planet and represent major centres of biological diversity (Junk 1996). The extreme diversity of habitats in such environments provide high environmental heterogeneity, due to the typical limnological characteristics found in each habitat, which may determine the species pattern distribution and elevated biodiversity. Among floodplain habitats, lakes can be considered more complex than rivers in physical structures and limnological factors (Margalef 1983).

The Upper Paraná river floodplain is the last remaining wetland area of the Paraná River that is not dammed in Brazil (Agostinho 1997, Gois et al. 2015). This area has high habitat diversity, which endows it with unique limnological characteristics that allows conservation of high species diversity (Thomaz et al. 1997, Thomaz et al. 2007). In this floodplain, great floods (a water level of over $4.5 \mathrm{~m}$ ) promote greater connectivity and homogenization between habitats (Thomaz et al. 2007), affecting aquatic communities (Agostinho et al. 2001) and changing ecosystem properties (Neiff 1990). However, the presence of reservoirs upstream of the Upper Paraná river (approximately 35 dams) controls the hydrological regime, influencing nutrient cycling, and therefore, the structure and composition of communities within this system (Agostinho et al. 2000, 2008, 2009, Stevaux et al. 2009, Souza-Filho et al. 2010). Flood periods in these areas have been found to have reduced frequency, duration, and intensity, thus increasing the periods of low water and drought in these environments (Souza-Filho 2009). In this context, it is expected that global drought events would be more frequent in the near future due to climate change and decreases in precipitation (Barnett et al. 2005, Woodwand et al. 2010).

The presence and distribution of algae in aquatic environments is a strong indicator of the physical and chemical conditions of these sites (Biggs 1996, Stevenson 1997, Moschini-Carlos \& Henry 1997, Domitrovic et al. 2013, Moresco \& Rodrigues 2013, Rodrigues et al. 2013). In floodplains, periphytic algae is responsible for part of the primary production, is the principal source of organic carbon deposition, plays an important role in mineralization and nutrient cycling, and is the base of the food web for many organisms (Stevenson 1996, Felisberto \& Murakami 2013). These organisms are influenced by several factors in the floodplain, such as the water level, current flow, macro and micro nutrients, light, temperature, predation, and the substrate type (Rodrigues et al. 2003, Algarte et al. 2014, Dunck et al. 2016). The alterations caused by drought events and changes in water level also affect these communities, particularly in the availability of substrates for adhesion, reproduction and development (Stevenson 1996). Furthermore, in periods of drought, algae species tend to be more persistent and endure the drought despite the disturbance, compared with how they react in periods of flood (Schneck 2011).

In this context, we aimed to evaluate the periphytic algae community in floodplain lakes and rivers in drought conditions, taking into account the importance of studying drought events in a quickly changing world. We aimed to answer the following questions surrounding the lake and river: i) What is the pattern of the periphytic algae attributes (composition, richness, density and diversity) in each type of environment (lentic or lotic) in drought conditions? ii) What are the main local abiotic factors in the community structuring in both environments in drought conditions? We hypothesize that diatoms are more frequent at both sites, over green algae and desmids, due to their resistance characteristics (Round et al. 1990, Passy 2007). Between sites, we hypothesize that higher periphyton algal richness, density and diversity occurs in the lake due to the greater availability of nutrients and the absence of flow (Rodrigues \& Bicudo 2001, Stevenson 1996) and habitat complexity. Then a record of aquatic community structure during this event may help us understand how organisms may behave in the face of climate change and droughts. Furthermore, we believe our study may provide evidence that is potentially applicable to future drought scenarios in wetlands worldwide.

\section{Materials and Methods}

The study was carried out at two sites, the Finado Raimundo lake

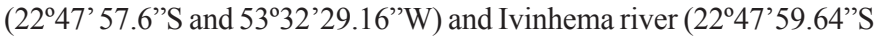
e 5332' 21.3”W) of the Upper Paraná river floodplain, which belong to the State Park of Ivinhema River, State of Mato Grosso do Sul, Brazil. The Ivinhema river runs parallel to the Paraná river in its lower reaches (sampled area), connecting to the Baia river by the Curutuba channel and to the Paraná river by the Ipoitã channel. The Finado Raimundo lake has an elongated shape and is approximately $2.9 \mathrm{~km}$ in length with an average width of $500 \mathrm{~m}$, connecting to the Paraná river through a channel 50-m long and 20-m wide (Souza-Filho et al. 2000) (Figure 1).

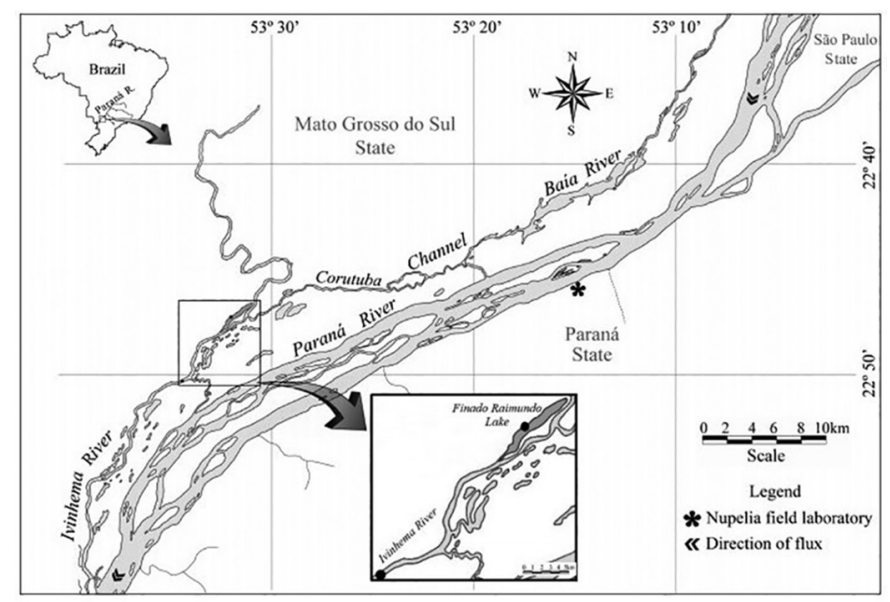

Figure 1. Upper Paraná river floodplain and the location of the Ivinhema river and Finado Raimundo lake.

The samplings were performed three times in 2011 during drought conditions (low water period, June, September and December) because there was no direct influence of the Paraná river on the study sites (Ivinhema River and Finado Raimundo Lake, Table 1).

In each sampling, limnological variables were sampled (simultaneously to biotic sample) in the subsurface of the limnetic zone in both environments. The following variables were measured: depth (m), water temperature $\left({ }^{\circ} \mathrm{C}\right.$ ) (oxímetro- YSI55A), dissolved oxygen (mg. $\left.\mathrm{L}^{-1}\right)$ (oximeter- YSI55A), conductivity $\left(\mu \mathrm{S} . \mathrm{cm}^{-1}\right)$ and $\mathrm{pH}$ (Digimed digital potentiometers), turbidity (NTU) (turbidimeter- LaMotte2020e), inorganic and organic dissolved solids $\left(\mathrm{mg} . \mathrm{L}^{-1}\right)$, total alkalinity $\left(\mu \mathrm{Eq} . \mathrm{L}^{-1}\right.$, Carmouze 1994), ammonium $\left(\mathrm{NH}_{4}^{+}\right)$, orthophosphate $\left(\mathrm{PO}_{4}^{++}\right)$, total nitrogen and total phosphorus $\left(\mu \mathrm{g} . \mathrm{L}^{-1}\right)$ (Table 1$)$. Water samples were filtered through Whatman $\mathrm{GF} / \mathrm{F}$ filters, under low pressure $(<0.5 \mathrm{~atm})$ and stored at $-20^{\circ} \mathrm{C}$ for later determination of the dissolved nutrient 
Periphytic algae under low water conditions

Table 1. Morphometric and limnological parameters of Finado Raimundo lake and Ivinhema river in the Upper Paraná River floodplain during sampling in 2011. $\left(\mathrm{NH}_{4}^{+}\right)$: ammonium, $\left(\mathrm{PO}_{4}^{++}\right)$: orthophosphate.

\begin{tabular}{|c|c|c|c|c|c|c|}
\hline \multirow{2}{*}{ Variables } & \multicolumn{3}{|c|}{ Lake Finado Raimundo } & \multicolumn{3}{|c|}{ River Ivinhema } \\
\hline & June & September & December & June & September & December \\
\hline Depth (m) & 4 & 4.25 & 3.5 & 4.5 & 4.3 & 4 \\
\hline Dissolved $\mathrm{O}_{2}\left(\mathrm{mg} \mathrm{L}^{-1}\right)$ & 7.72 & 10.02 & 6.99 & 7.92 & 7 & 6.31 \\
\hline $\mathrm{pH}$ & 6.57 & 8.95 & 7.01 & 7.23 & 7.09 & 6.77 \\
\hline Inorganic dissolved solids (mg L-1) & 0.35 & 0.47 & 0.09 & 2.6 & 7 & 2.26 \\
\hline Dissolved organic solids (mg L ${ }^{-1}$ ) & 0.3 & 1.19 & 0.54 & 0.55 & 1.64 & 0.64 \\
\hline Alkalinity $\left(\mathrm{mEq} \mathrm{L} \mathrm{L}^{-1}\right)$ & 172 & 441.3 & 342.2 & 190.3 & 323.1 & 339.4 \\
\hline Total Nitrogen (ug L-1) & 764 & 1226.4 & 1319.6 & 725.9 & 1101.1 & 790.5 \\
\hline
\end{tabular}

fractions and suspended material (Bergamin et al. 1978, Mackereth et al. 1978) (Table 1). The daily water level of the Paraná river is available at http://www.peld.uem.br/.

Two banks of the macrophyte Eichhornia azurea (Sw.) Kunth were sampled in each environment (lake and river) and these same banks were used in all samplings. These macrophyte banks were located in opposite margins. In each macrophyte bank it was selected a random branch and periphytic algae were collected from the sixth or seventh plant internode. In each environment we collected two petioles, totaling two sub-samples per site, and all together totaling twelve samples in the study. The general pattern of results are reported as the sample means for each environment per month. The periphytic material was taken by scraping part of the E. azurea petioles, using a stainless-steel blade wrapped in aluminium foil and jets of distilled water (Bicudo 1990, Schwarzbold 1990). The area scraped from the substrate $\left(\mathrm{cm}^{2}\right)$ was calculated from measurements of the length and width of each petiole. The material removed was preserved with acidified $(0.5 \%$ acetic acid) Lugol's solution for later counting, and the material for the qualitative analysis was preserved in Transeau's solution at a ratio of 1:1 as recommended by Bicudo \& Menezes (2006).

The periphytic algal samples were quantified using sedimentation chambers in an Olympus ${ }^{\circledR}$ M021 inverted microscope following the Utermöhl method (1958). The counts were carried out in random fields until reaching at least 100 individuals (cells, colonies, or filaments) from the most common species in each sample and according to the species accumulation curve following Ferragut \& Bicudo (2012). Qualitative analyses were performed by temporary glass slides in a binocular optical microscope, with micrometre oculars of 400x and 1000x, for species identification alone. The species identification was performed using classical literature such as Prescott (1982), Round et al. (1990), Bourrelly \& Couté (1991), Dillard (1991), John et al. (2002), Wehr $\&$ Sheath (2003) and Bicudo \& Menezes (2006) and regional studies (Fonseca \& Rodrigues 2005a, Moresco \& Rodrigues 2006, Biolo $\&$ Rodrigues 2010, 2011, Bartozek et al. 2013) for reference. The classification system adopted was that proposed by Round $(1965,1971)$.
Species density was estimated according to Ros (1979), and the results were expressed as number of individuals per unit area (ind $\mathrm{cm}^{-2}$ ). The algal richness was estimated from algal density, using the species accumulation curve. We determined the dominance and abundance of species as proposed by Lobo \& Leighton (1986), where the dominant species are those with densities greater than $50 \%$ of the total density of the community, and the abundant species were those with densities exceeding the mean population density of each sample. The species diversity was estimated by the Shannon-Weaver index (1963) for the sites in all samplings.

\section{Data analysis}

A principal component analysis (PCA) was applied to analyse the spatial and temporal variation of limnological variables of the environments. We tested the correlation of limnological variables to avoid multicollinearity and used water temperature, dissolved oxygen, conductivity, $\mathrm{pH}$, turbidity, inorganic and organic dissolved solids, ammonia and orthophosphate for this analysis. The data were previously standardized [(Xij-Xi)/Si] (Legendre \& Legendre 1998). Axis retention was evaluated under the broken-stick criterion (Jackson 1993).

T-tests were used to test for differences in community attributes (richness, density and diversity) between the environments (the lake and the river). A nonmetric multidimensional scaling (NMDS) was applied to the dominant and abundant species matrix to investigate the species distribution in the sites for all samplings. The Bray-Curtis index was used to calculate the distances and check the stress level of adjustment of the newly generated axes and the ordering of the dissimilarity matrix (Legendre \& Legendre 1998). The analyses were performed using $\mathrm{R}$ software version 3.1.2 (R Development Core Team 2014) and graphics in Statistica, version 7.1 (StatSoft 2005).

\section{Results}

The PCA results showed that $77.5 \%$ of the limnological data variability was summarized in the first two axes with eigenvalues 3.51 and 3.45, respectively. The first axis was most influenced by $\mathrm{pH}$ (loading 
$\mathrm{r}=0.95$ ) and turbidity (loading $\mathrm{r}=0.21$ ) (Figure 2). The second axis had a greater relationship with turbidity (loading $r=0.70$ ) and inorganic dissolved solids (loading $r=0.57$ ) (Figure 2). The PCA 1 axis showed a temporal difference between the samplings, with similarity between LS and RS; and in the other side RJ and LJ (Figure 2). The second axis showed differences between the river and the lake (Figure 2). In general, the lake was more influenced by dissolved oxygen (DO) and $\mathrm{NH}_{4}^{+}$, whereas the river was most influenced by dissolved solids, conductivity and $\mathrm{PO}_{4}^{++}$(Table 1).

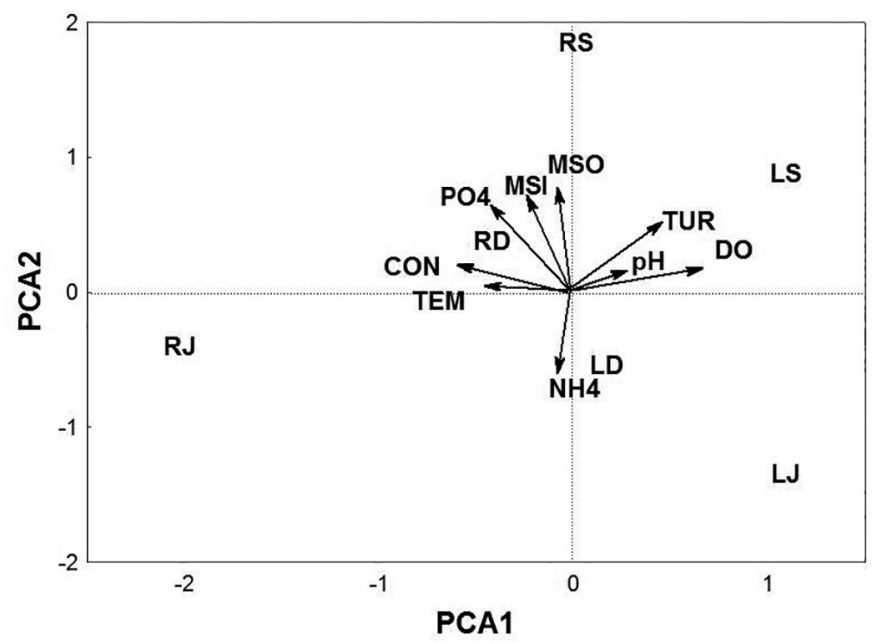

Figure 2. Site scores derived from a principal component analysis applied to the limnological dataset. (LJ): Lake sampling in June, (LS): Lake sampling in September, (LD): Lake sampling in December, (RJ): River sampling in June, (RS): River sampling in September, (RD): River sampling in December, $(\mathrm{CON})$ : conductivity, (NH4): ammonium, (TEM): temperature, (PO4): orthophosphate, (MSI): inorganic dissolved solids, (MSO): dissolved organic solids, (ALK): total alkalinity, (NT): total nitrogen, (DO): dissolved oxygen, (TUR): turbidity.

We found 171 species and the lake was represented by 104 species divided into eight classes presented in the following descending order: Bacillariophyceae, Zygnemaphyceae, Chlorophyceae, Cyanophyceae, Chrysophyceae, Euglenophyceae, Oedogoniophyceae and Xanthophyceae (Figure 3a). The river was characterized by 80 species distributed among six classes: Bacillariophyceae, Zygnemaphyceae, Chlorophyceae, Cyanophyceae, Oedogoniophyceae and Rhodophyceae (Figure 3b). Chrysophyceae, Euglenophyceae and Xanthophyceae belong exclusively to the lake, whereas species belonging to Rhodophyceae were found only in the river.

Among the species found in both sites (supplementary material), 13 species were common to both environments, with 10 species belonging to Bacillariophyceae (Achnanthidium minutissimum (Kützing) Czarnecki, Fragilaria capucina Desmazières, Frustulia saxonica Rabenhorst, Gomphonema parvulum (Kützing) Kützing, Melosira varians C. Agardh, Navicula cryptotenella Lange-Bertalot, Nitzschia palea (Kützing) W. Smith, Pinnularia latarea Krammer, Synedra goulardii Brébisson ex Cleve and Grunow and Ulnaria ulna (Nitzsch) P. Compère), two species belonging to Zygnemaphyceae (Closterium leibleinii Kützing ex Ralfs and Staurastrum trifidum Nordstedt) and one species belonging to Chlorophyceae (Stigeoclonium sp.).
The lake had a species density 2.45 times higher than the river $(t=2.45, p=0.02$, Fig. 4). Bacillariophyceae was the most abundant class in both environments (Figure 4). The most abundant species in the two environments were $A$. minutissimum and $N$. palea. In the river, $M$. varians was the most abundant species, and in the lake, F. capucina was most abundant species. September was the month that both sites showed the highest species richness and density (Figures 3 and 4).

There was no mean difference in species richness between the sites $(t=1.87, p=0.13)$ and a similar pattern was found for species diversity $(\mathrm{t}=1.79, \mathrm{p}=0.14)$. In contrast, the NMDS showed a clearly difference between the communities in both types of environments (stress $=0.065)($ Fig. 5). Among the river species, the most abundant in June were Frustulia pumilio Lange-Bertalot and U. Rumrich (Frp), Encyonema silesiacum (Bleisch) D.G. Mann (Eco) and Gomphonema gracile Ehrenberg (Gog) (Figure 5). In September, the most abundant species were Nitzschia clausii Hantzsch (Nic) and Surirella angusta Kützing (Sui), and in December, the most abundant species were Gomphonema pumilum (Grunow) E. Reichard and Lange-Bertalot (Gol) and Gomphonema mexicanum Grunow (Gom) (Figure 5). The Gomphonema species had the highest representation in the river. However, in the lake communities, the most abundant species in June were Oedogonium sp. 2 (Oem) and Oedogonium sp. 3 (Oep) (Figure 5). The most abundant species in September was Gomphonema brasiliense Grunow (Goe), and the most abundant species in December were $F$. capucina (Frc) and N. palea (Nip) (Figure 5).

\section{Discussion}

Climate change represents a complex amalgam of stressors, which include the increased frequency and intensity of droughts and extreme flow events (Woodward et al. 2010). This study demonstrated that in low water levels, diatoms are predominant in both sites. Between the environments, there are different patterns in periphytic algal community structure, which agrees with our hypothesis. These differences were attributed mainly due to the physical and chemical characteristics of the lake and the river and their different hydrodynamics (Rodrigues et al. 2003).

There is an important spatial and temporal variability in the limnological characteristics of the Upper Paraná river floodplain habitats (Thomaz et al. 2004, Algarte et al. 2006). Studies in this floodplain that have evaluated periods of both high and low water levels have shown that diatoms dominate the periphyton under these two hydrological conditions (Fonseca \& Rodrigues 2005b, Algarte et al. 2006, Biolo \& Rodrigues 2013, Carapunarla et al. 2014). In these studies, at low water levels, the diatoms were favoured by environmental conditions such as low temperatures and concentrations of phosphorus forms, higher concentrations of dissolved oxygen and nitrogen for both environments. In the present study, both environments were related to the higher values of dissolved oxygen in June and September corroborating with these other studies. In general, the lake had higher values of nitrogen and dissolved oxygen, whereas the river had higher values of conductivity, suspended solids and phosphorus. The high values of dissolved oxygen in the lake and suspended solids in the river in June and September may explained the high density of diatoms, which, by having chlorophyll c, develop better in low-light conditions (Round et al. 1990). In the lake, the dominance of diatoms maybe by it be excellent competitors 

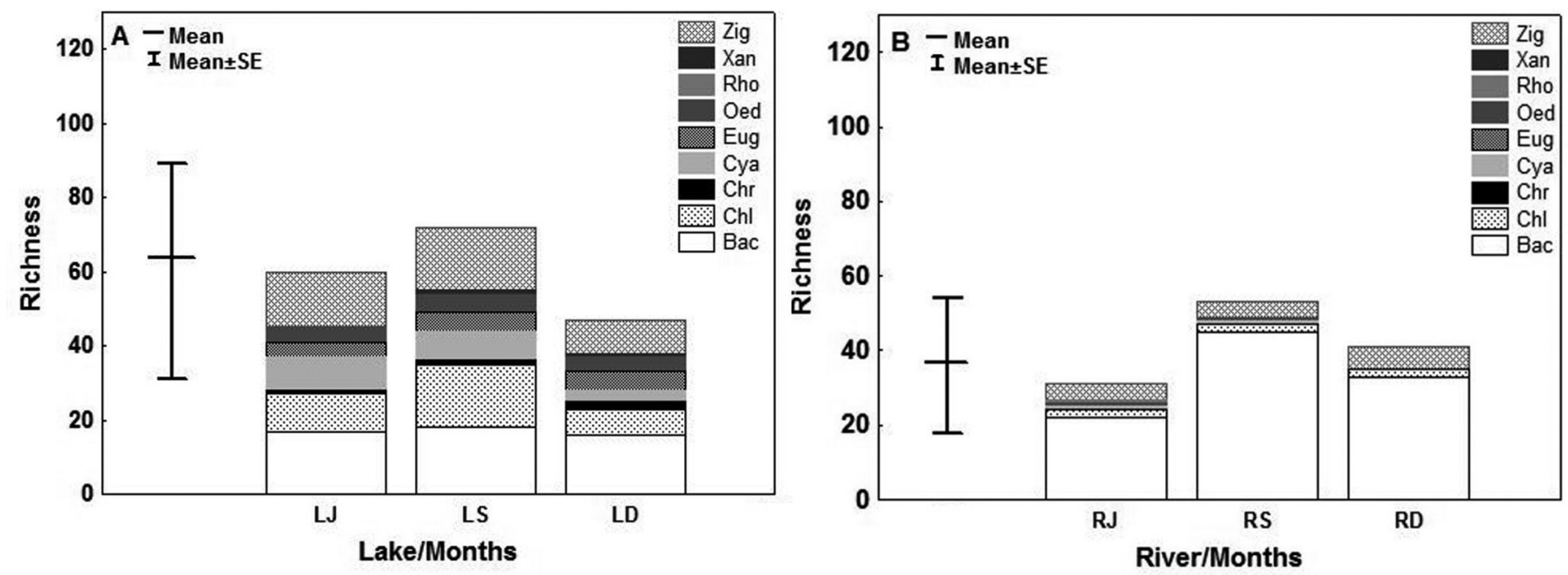

Figure 3. Algal richness (mean \pm standard error) during samplings and algal groups richness between sites (a: Lake; b: River) and samplings, (LJ): Lake sampling in June, (LS): Lake sampling in September, (LD): Lake sampling in December, (RJ): River sampling in June, (RS): River sampling in September, (RD): River sampling in December, (Bac): Bacillariophyceae, (Chl): Chlorophyceae, (Chr): Chrysophyceae, (Cya): Cyanophyceae, (Eug): Euglenophyceae, (Oed): Oedogoniophyceae, (Rho): Rhodophyceae, (Xan): Xanthophyceae, (Zig): Zygnemaphyceae.
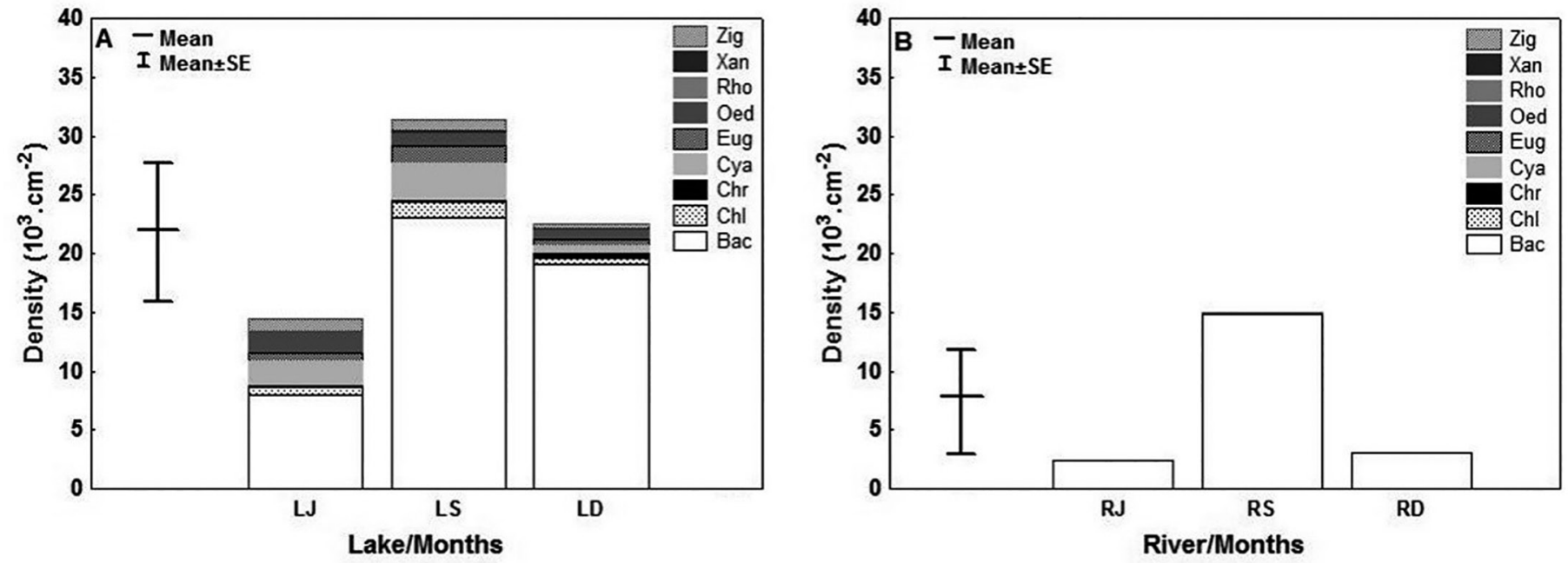

Figure 4. Algal density (mean \pm standard error) during samplings and algal group density between sites (a: Lake; b: River) and samplings, (LJ): Lake sampling in June, (LS): Lake sampling in September, (LD): Lake sampling in December, (RJ): River sampling in June, (RS): River sampling in September, (RD): River sampling in December, (Bac): Bacillariophyceae, (Chl): Chlorophyceae, (Chr): Chrysophyceae, (Cya): Cyanophyceae, (Eug): Euglenophyceae, (Oed): Oedogoniophyceae, (Rho): Rhodophyceae, (Xan): Xanthophyceae, (Zig): Zygnemaphyceae.

in turbid environments and low phosphorus concentrations (Cetto et al. 2004). Our results showed that physical variables are important factors to distinguish the limnological characteristics between lentic and lotic environments, which agrees with data by Rodrigues \& Bicudo (2001).

The richness and diversity of periphytic algae were not significantly different between environments, and thus, they were not the attributes that best explained the spatial difference between the lotic and lentic sites. However, the species composition and density values between the environments were clearly distinct. The highest values for algal densities were recorded in September for both sites, in agreement with Algarte et al. $(2006,2009)$ for environments of the same floodplain. September presented the lowest hydrometric water level, allowing the development of loosely attached species due to the higher hydrometric water level and resultant physical disturbance, which made permanence difficult for species attached to the substrate (Algarte et al. 2006). The community structuring demonstrated that Bacillariophyceae was predominant in the river as well as in the lake. Its highest density occurred in the lake, and species richness and diversity were similar between sites, whereas September showed higher values for species richness and density. The diatoms were predominant in both environments, possibly due to their fast and efficient colonization, occupying the substrates within one to several weeks (Stevenson 1996, Hoagland et al. 1986). Furthermore, many diatoms have specialized structures for attachment to the substrate, such as mucilaginous peduncles in the Gomphonema species and the production of mucilaginous matrices as in Frustulia and Navicula (Round 1991). The highest values for density and richness of diatoms in the lentic system is partly related to their specialized structures that 


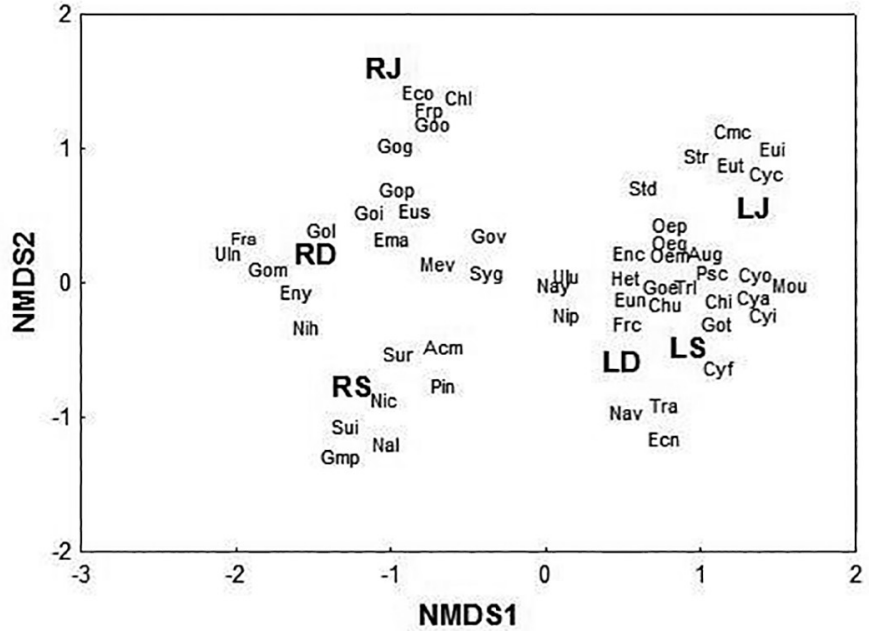

Figure 5. Nonmetric multidimensional scaling (NMDS) of periphytic algal communities between sites and samplings, (LJ): Lake sampling in June, (LS): Lake sampling in September, (LD): Lake sampling in December, (RJ): River sampling in June, (RS): River sampling in September, (RD): River sampling in December.

confer a competitive advantage over other species of different classes in stressful environmental conditions (Biggs 1996).

In term of species richness, the classes Zygnemaphyceae and Chlorophyceae were well represented in the lake. The presence of macrophyte stands in these sites favours the development of these groups because these plants release dissolved nutrients and reduce the turbulence of the water column (Rodrigues \& Bicudo 2001, Algarte et al. 2006). The desmids have a selective advantage in more protected environments, are less disturbed (low current flow), and have a relatively large size, which makes them difficult to be removed by herbivory. According to Coesel (1996), truly planktonic desmids are rare and most of them use at least one substrate to reproduce.

Chrysophyceae, Euglenophyceae and Xanthophyceae were exclusive of the lentic environment. The chrysophytes are opportunists, present rapid growth, are adapted to growing in vegetated areas, have flagella and adaptive strategies for using different resource sources as well as are more related to dry periods and environments with higher dissolved oxygen concentrations (Almeida \& Melo 2011, Golebski $\&$ Ferragut 2012). The euglenoids are optional heterotrophs and are commonly found in sediment (Wetzel 1983). The presence of these organisms in lentic environments may be related to a possible interaction with epipelic communities. The xanthophytes can benefit in environments with reduced depth, low transparency and medium levels of phosphorus, nitrate and ammonium (Bovo-Scomparin et al. 2005). Rhodophyceae occur only in lotic sites because they are typically found in environments with moderate current velocity, high transparency, and no organic pollution (Esteves 1998).

A. minutissimum and $N$. palea were the most abundant species in both sites. A. minutissimum is among the diatoms more often recorded in periphytic samples worldwide (Krammer \& Lange-Bertalot 1991, Round 2004). This species can occur in acidic to alkaline environments (Round 2004) and is oligotrophic to eutrophic (Leandrini et al. 2013, Dunck et al. 2015). N. palea is generally considered tolerant to organic pollution (Bes \& Torgan 2010) and may also have wide distribution, including lakes (Bes \& Torgan 2010), rivers (Rusanov et al. 2009), streams (Dunck et al. 2015), and floodplains (Weilhoefer \& Pan 2006).

In lotic environments, $M$. varians was the most abundant species. In contrast, McIntire (1968) showed these algae were more abundant in lentic environments. However, Fogg \& Reimer (1995) reported that $M$. varians is cosmopolitan and can be found in a large range of ecological conditions, and its density is not determined by physical factors such as current velocity flow. F. capucina was important for both environments; however, this species was more abundant in the lake. Lobo et al. (2004) reported this species as highly tolerant to eutrophication, although there are studies that consider this species related to less polluted waters (Ten Cate et al. 1993) or very tolerant to low nutrient supplies (Hinojosa-Garro et al. 2010). Thus, these conflicting results concerning the response of $F$. capucina to environments suggest that it is a cosmopolitan species.

The NMDS results showed that more species of genus Gomphonema discriminated the lotic site (G. pumilum, G. mexicanum and G. gracile). The Gomphonema genus has several cosmopolitan species and is well represented in richness and density in aquatic environments, usually in lotic environments (Tremarin et al. 2009). This species has cells that are typically attached to solid substrates by pads or mucilaginous peduncles (Hoagland et al. 1982, Burliga \& Schwarzbold 2013), making this species more resistant to disturbances.

Other species that were more abundant in the river compared with the lake were E. silesiacum, $N$. clausii and S. angusta. Salomani \& Torgan (2008) observed the presence of E. silesiacum in sites with low concentration of organic matter, in contrast with our results, as the river contained more suspended organic material. September was a period in which inorganic dissolved solids and total nitrogen were high, which may have contributed to the high density of $N$. clausii and S. angusta in the river.

Oedogoniophyceae were abundant in the lake, especially those of the Oedogonium genus. These algae increase the colonization surface, serving as a substrate for other algal classes, such as Bacillariophyceae (Carapunarla et al. 2014). These species are typically periphytic and can be found attached to many types of substrates (Lee 2008). They are efficient competitors for resources such as light and space and are associated with high concentrations of nutrients, electrical conductivity (Cavati \& Fernandes 2008) and lower current velocity (Biggs 1996, Simons 1994), as in the present lentic environment.

In summary, we conclude that in floodplain drought conditions, periphytic algal species composition and density responded better to the effects of site hydrodynamics than algal richness and diversity. Diatoms were predominant in both sites due to their strategic traits, and between sites, there were different patterns in periphytic algal community structure, owing to the physical and chemical characteristics of the lake and the river. Our study revealed the primary importance of conductivity, suspended solids and phosphorus for the river and turbidity and nitrogen for the lake as abiotic local factors in periphytic algae structuring in drought conditions in the Upper Paraná river floodplain. Therefore, we have improved our understanding of the processes that govern the periphyton algal community in floodplain drought conditions. 
Periphytic algae under low water conditions

\section{Supplementary material}

Supplement 1. Species occurrence (and its respective abbreviations) at the lentic and lotic environments in the sampling months. (LJ): Lake sampling in June, (LS): Lake sampling in September, (LD): Lake sampling in December, (RJ): River sampling in June, (RS): River sampling in September, (RD): River sampling in December.

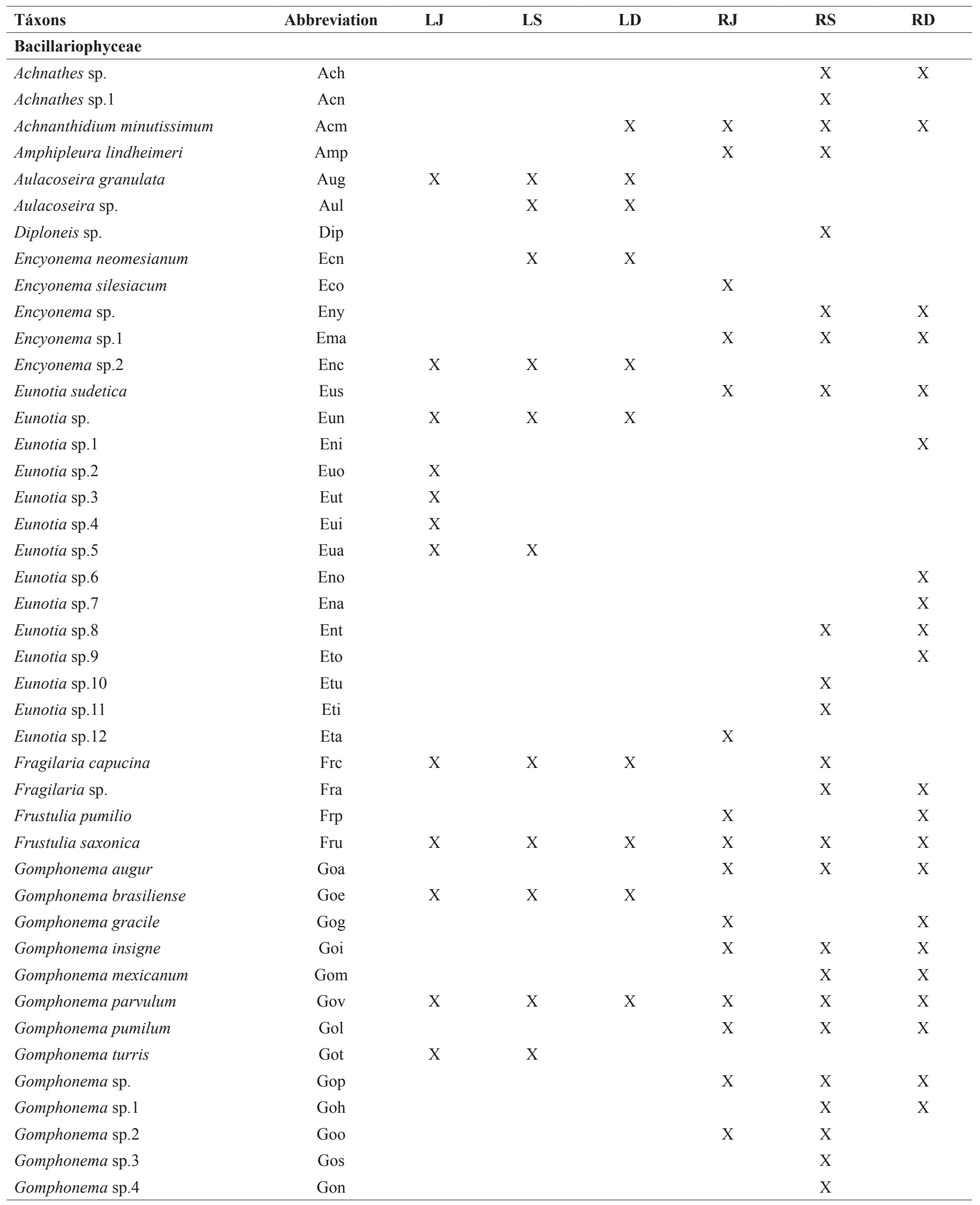


Bichoff, A. et al.

Continued Supplement 1.

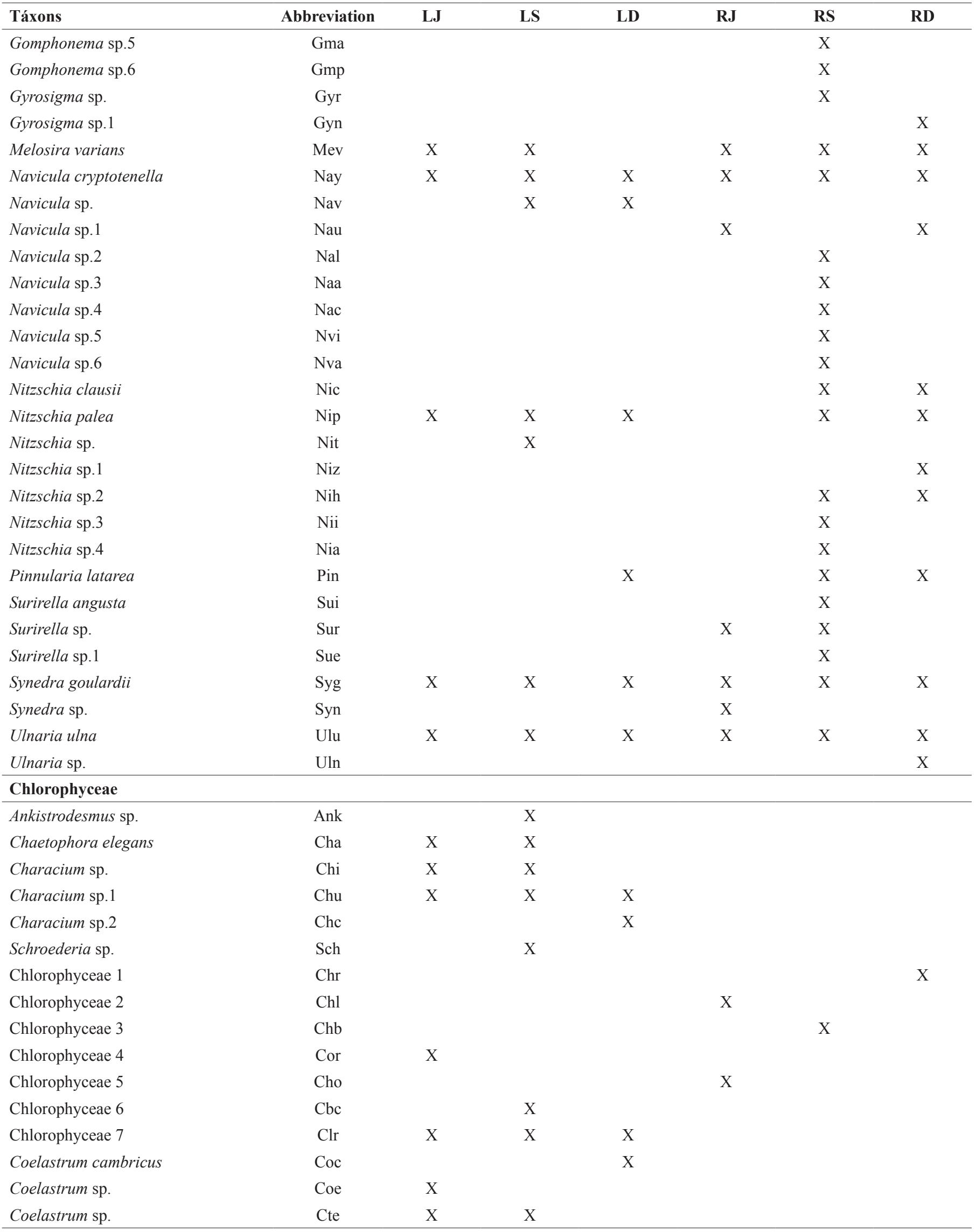


Continued Supplement 1.

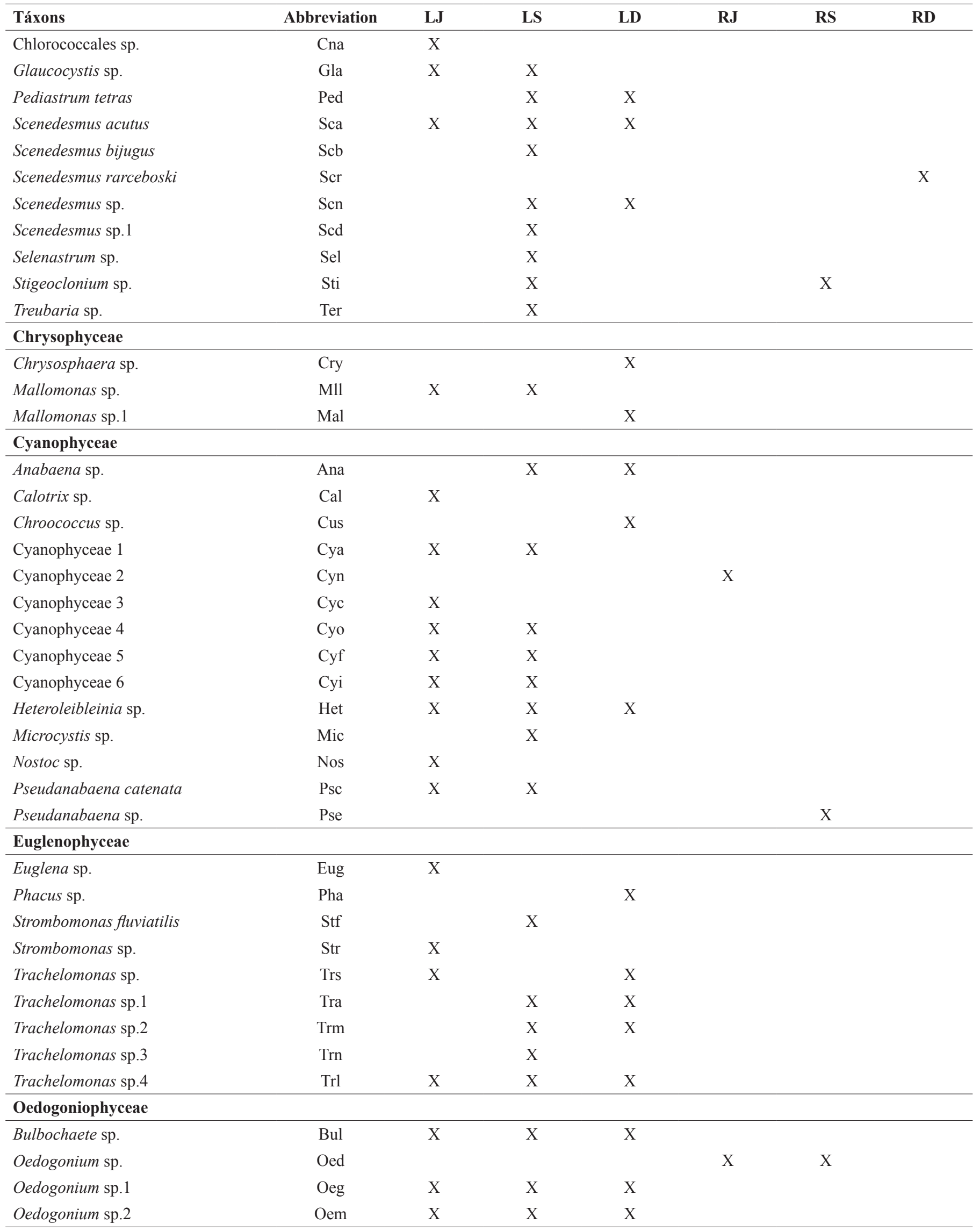


Bichoff, A. et al.

Continued Supplement 1.

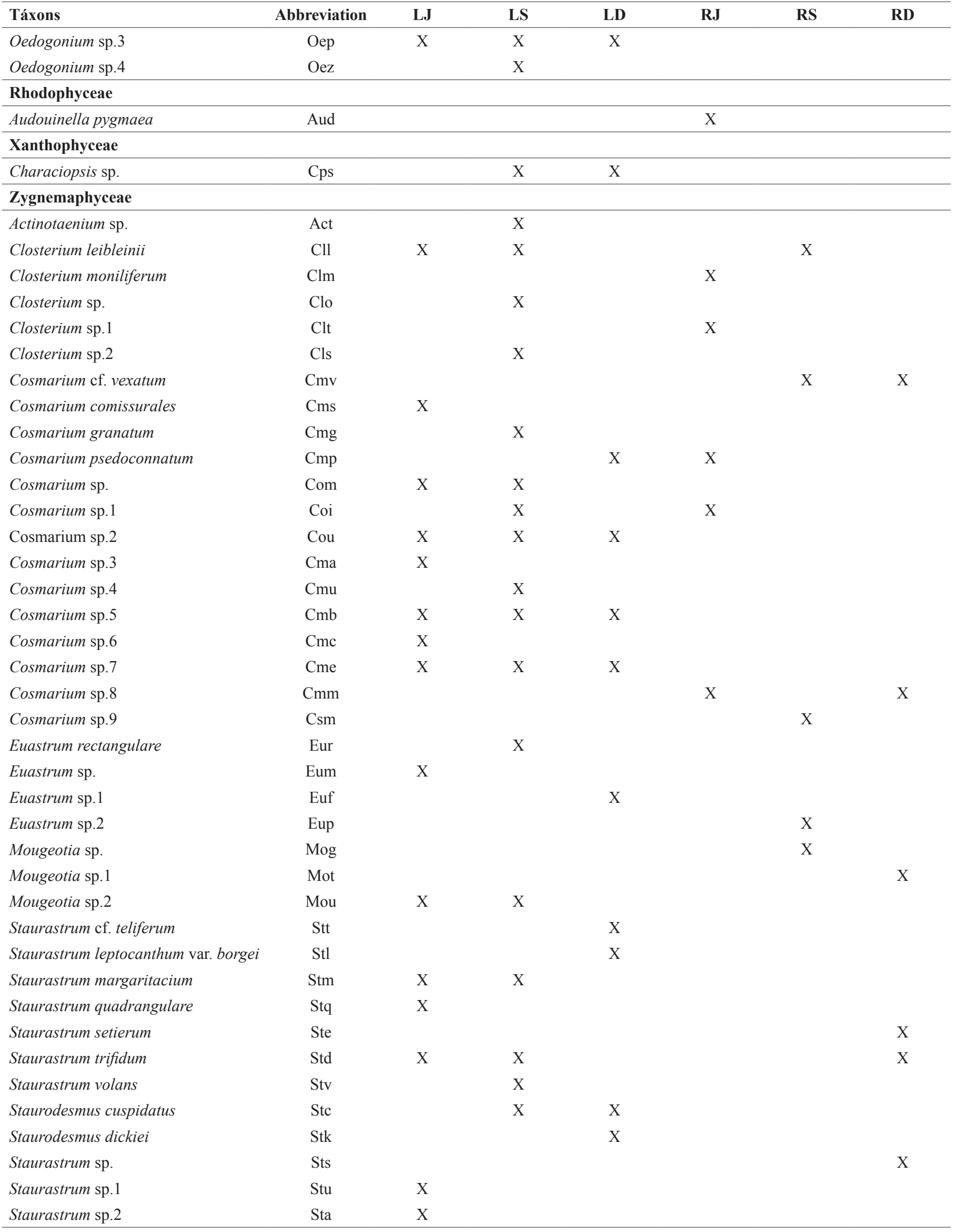




\section{Acknowledgements}

This study was supported by the Long Term Ecological Research Program (PELD-CNPq). We acknowledge Coordenação de Aperfeiçoamento de Pessoal de Nível Superior (CAPES) for a master scholarship granted to Bichoff, A. and a post-doctoral scholarship granted to Dunck, B.; Conselho Nacional de Desenvolvimento Científico e Tecnológico (CNPq) for a master scholarship granted to Osório, N.C. and a productivity grant granted to Rodrigues, L.; Núcleo de Pesquisas em Limnologia, Ictiologia e Aquicultura (Nupélia) for technical and logistical support; Roberto, M.C. and the Laboratory of Limnology of Nupélia for the analysis of limnologic variables, and Mormul, R.P. for comments on an earlier version of this manuscript.

\section{References}

AgOSTINHO, A.A. 1997. Qualidade dos habitats e perspectivas para a conservação. In A Planície de inundação do alto rio Paraná: aspectos físicos, biológicos e socioeconômico (A.E.M.A. Vazzoler, A.A. Agostinho \& N.S. Hahn, eds). Eduem: Maringá, p.455-460.

AGOSTINHO, A.A., THOMAZ, S.M., MINTEVERA, C.V. \& WINEMILLER, K.O. 2000. Biodiversity in the high Paraná river floodplain. In Biodiversity in wetlands: assessment, function and conservation (B. Gopal, W.J. Junk \& J.A DAVIS, eds). Backhuys Publishers, Leiden, p.89-118.

AGOSTINHO, A.A., GOMES, L.C. \& ZALEWZKI, M. 2001. The importance of floodplains for the dynamics of fish communities of the upper river Paraná. Ecohydrol. Hydrobiol., 1(1-2):209-217.

AGOSTINHO, A.A., PELICICE, F.M. \& GOMES, L.C. 2008. Dams and the fish fauna of the Neotropical region: impacts and management related to diversity and fisheries. Braz. J. Biol., 68(4, Suppl.):1119-1132.

AGOSTINHO, A.A., BONECKER, C.C. \& GOMES, L.C. 2009. Effects of water quantity on connectivity: the case of the Upper Paraná river floodplain. Ecohydrol. Hydrobiol., 9(1):99-113.

ALGARTE, V.M.; MORESCO, C. \& RODRIGUES, L. 2006. Algas do perifiton de distintos ambientes na planície de inundação do alto rio Paraná. Acta Sci. Biol. Sci., 28(3):243-251.

ALGARTE, V.M., RODRIGUES, L., LANDEIRO, V.L., SIQUEIRA T. \& BINI, L.M. 2014. Variance partitioning of deconstructed periphyton communities: does the use of biological traits matter? Hydrobiologia, 722:279-290.

ALGARTE, V.M., SIQUEIRA, N.S., MURAKAMI, E.A. \& RODRIGUES, L. 2009. Effects of hydrological regime and connectivity on the interannual variation in taxonomic similarity of periphytic algae. Braz. J. Biol., 69(2 Suppl.):609-616.

ALMEIDA, F.F. \& MELO, S. 2011. Estrutura da comunidade fitoplanctônica de um lago de inundação amazônico (Lago Catalão, Amazonas, Brasil). Neotrop. Biol. Conserv., 6(2):112-123.

BARNETT, T.P., ADAM, J.C \& LETTENMAIER, D.P. 2005. Potential impacts of a warming climate on water availability insnow-dominated regions. Nature, 438:303-309.

BARTOZEK, E.C.R., LUDWIG, T.A.V., TREMARIN, P.I., NARDELLI, M.S., BUENO, N.C. \& ROCHA, A.C.R. 2013. Diatoms (Bacillariophyceae) of Iguaçu National Park, Foz do Iguaçu, Brazil. Acta Bot. Bras., 27(1):108-123.

BERGAMIN, H., REIS, B.F. \& ZAGATO, E.A.G. 1978. A new device for improving sensitivity and stabilization in flow injection analysis. Anal Chim. Acta, 97:427-431.

BES, D. \& TORGAN, L.C. 2010. O gênero Nitzschia (Bacillariaceae) em ambientes lacustres na Planície Costeira do Rio Grande do Sul, Brasil. Rodriguésia, 61(3):359-382.

BICUDO, C.E.M, 1990. Metodologia para o estudo qualitativo das algas do perifiton. Acta Limnol. Brasil., 3: 477-491

BICUDO, C.E.M \& MENEZES, M. 2006. Gêneros de algas de águas continentais do Brasil: chaves para identificação e descrições. 2 ed. Rima, São Carlos.
BIGGS, B.J.F. 1996. Patterns in benthic algal of streams. In Algal ecology: freshwater benthic ecosystems (R.J. Stevenson, M.L. Bothwell \& R.L. Lowe, eds). Academic Press, San Diego, p.31-56.

BIOLO, S. \& RODRIGUES, L. 2010. New records of Xanthophyceae and Euglenophyceae in the periphytic algal community from a neotropical river floodplain, Brazil. Algol. Stud., 135:61-81.

BIOLO, S. \& RODRIGUES, L. 2011. Composição de algas perifíticas (exceto Bacillariophyceae) em distintos substratos naturais de um ambiente semilótico, planície de inundação do Alto Rio Paraná, Brasil. Ver. Bras. Bot., 34:307-319.

BIOLO, S. \& RODRIGUES, L. 2013. Structure of the periphytic algae associated with a floating macrophyte in an open lake on the Upper Paraná river floodplain, Brazil. Acta Sci. Biol. Sci., 35(4):513-519.

BOURRELLY, P. \& COUTÉ, A. 1991. Desmidiées de Madagascar (Chlorophyta, Zygophyceae). J. Cramer, Stuttgart.

BOVO-SCOMPARIN, V.M., BORGES P.A.F., TRAIN, S. \& RODRIGUES, L.C. 2005. Xanthophyceae planctônicas da planície de inundação do alto rio Paraná. Acta Sci. Biol. Sci., 27(1):9-20.

BURLIGA, A.L. \& SCHWARZBOLD, A. 2013. Perifíton: diversidade taxonômica e morfológica. In Ecologia do perifíton (A. Schwarzbold, A.L. Burliga \& L.C. Torgan, eds) Rima, São Carlos, p.1-6.

CARAPUNARLA, L., BAUMGARTNER, D. \& RODRIGUES, L. 2014. Community structure of periphytic algae in a floodplain lake: a long-term study. Acta Sci. Biol. Sci., 36:147-154.

CARMOUZE, J.P. 1994. O metabolismo dos ecossistemas aquáticos: fundamentos teóricos, métodos de estudo e análises químicas. Edgard Blücher, Fapesp, São Paulo, p.254

CAVATI, B. \& FERNANDES, V.O. 2008. Algas perifíticas em dois ambientes do baixo rio Doce (lagoa Juparanã e rio Pequeno - Linhares, Estado do Espírito Santo, Brasil): variação espacial e temporal. Acta Sci. Biol. Sci., 30:439-448.

CETTO, J.M., LEANDRINI, J.A., FELISBERTO, S.A. \& RODRIGUES, L. 2004. Comunidade de algas perifíticas no reservatório de Iraí, Estado do Paraná, Brasil. Acta Sci. Biol. Sci. 26(1):1-7.

COESEL, P.F.M. 1996. Biogeography of desmids. Hydrobiologia, 336:41-53.

DILLARD, G.E. 1991. Freshwater algae of the southeastern united states. J. Cramer, Stuttgart.

DOMITROVIC, Y.Z., NEIFF, J.J. \& VALLEJOS, S.V. 2013. Factores que regulan la distribution y abundancia del perifiton em ambientes lenticos. In Ecologia do perifiton (A. Schwarzbold, A.L. Burliga \& L.C. Torgan, eds). Rima, São Carlos, p.103-130.

DUNCK, B., LIMA-FERNANDES, E., CÁSSIO, F., CUNHA, A., RODRIGUES, L. \& PASCOAL, C. 2015. Responses of primary production, leaf litter decomposition and associated communities to stream eutrophication. Environ. Pollut., 202:32-40.

DUNCK, B., SCHNECK, F. \& RODRIGUES, L. 2016. Patterns in species and functional dissimilarity: insights from periphytic algae in subtropical floodplain lakes. Hydrobiologia, 763(1):237-247.

ESTEVES, F.A. 1998. Fundamentos de Limnologia. 2 ed. Interciência/FINEP, Rio de Janeiro.

FELISBERTO, S.A. \& MURAKAMI, E.A. 2013. Papel do perifiton na ciclagem de nutrientes e na teia trófica. In Ecologia do perifíton (A. Schwarzbold, A.L. Burliga \& L.C. Torgan, eds). Rima, São Carlos, p.23-44.

FERRAGUT, C. \& BICUDO, D.C. 2012. Effect of N and P enrichment on periphytic algal community succession in a tropical oligotrophic reservoir. Limnology, 13:131-141.

FOGG, G.E. \& REIMER, C.W. 1965. Environmental requirements of plankton algae and their effects on water quality: diatoms and their physico-chemical environment. In: Biological Problems in Water Pollution Seminar, 3, Cincinnati, Ohio, 1962. Cincinnati, Ohio: U.S. Department of Health, Education, and Welfare, Public Health Service, Division of Water Supply and Pollution Control., p.19-28.

FONSECA, I.A. \& RODRIGUES, L. 2005a. Cianobactérias perifíticas em dois ambientes lênticos da planície de inundação do alto Rio Paraná, PR, Brasil. Braz. J. Biol., 28(4):821-834. 
FONSECA, I.A. \& RODRIGUES, L. 2005b. Comunidade de algas do perifiton em distintos ambientes da planície de inundação do alto rio Paraná. Acta Sci. Biol. Sci., 27(1):21-28.

GOIS, K.S., PELICICE, F., GOMES, L.C., AGOSTINHO, A.A. 2015. Invasion of an Amazonian cichlid in the Upper Paraná River: facilitation by dams and decline of a phylogenetically related species. Hydrobiologia, 746: 401-413.

GOLEBSKI, B.P. \& FERRAGUT, C. 2012. Variação sazonal e sucessional da comunidade de algas perifíticas em substrato natural em um reservatório mesotrófico tropical. Acta Bot. Bras., 26:810-821.

HINOJOSA-GARRO, D., MASON, D.F. \& UNDERWOOD, G.J.C. 2010. Influence of macrophyte spatial architecture on periphyton and macroinvertebrate community structure in shallow water bodies under contrasting land management. Fundam. Appl. Limnol., 177:19-37.

HOAGLAND, K.D., ROEMER, S.C. \& ROSOWSKI, J.R. 1982. Colonization and community structure of two periphyton assemblages, with emphasis on the diatoms (Bacillariophyceae). Am. J. Bot., 69: 188-213.

HOAGLAND, K.D., ZLOTSKY, A. \& PETERSON, C.G. 1986. The source of algal colonizer on rock substrates in a freshwater impoundment. In Algal biofouling (L.V. Evans \& Hoagland, K.D., eds). Elsevier Science Publishing Company.

JACKSON, D.A. 1993. Sttoping rules in principal components analysis: a comparison of heuristical and statistical approaches. Ecology, 74:2204-2214.

JOHN, D.M., WHITTON, B.A. \& BROOK, A.J. 2002. The freshwater algal flora of the britishisles: an identification guide to freshwater and terrestrial algae. Cambridge University Press, Cambridge.

JUNK, W.J. 1996. Ecology of floodplains: a challenge for tropical limnology. In Perspectives in tropical limnology (F. Schiemer \& K.T. Boland, eds). Academic Publishing, p.255-265.

KRAMMER, K. \& LANGE-BERTALOT, H. 1991. Süßwasserflora von Mitteleuropa. Bacillariophyceae 3. Teil: Centrales, Fragilariaceae, Eunotiaceae. Spektrum, Heidelberg and Berlin.

LEANDRINI, J.A., FELISBERTO, S. A. \& DUNCK, B. 2013. Estrutura da comunidade de algas perifíticas em distintas Veredas no cerrado goiano. Rev. Biol. Neotrop., 10(1):9-20.

LEE, R.E. 2008. Phycology. Cambridge University Press, Cambridge.

LEGENDRE, P. \& LEGENDRE, L. 1998. Numerical ecology. Elsevier Science, Amsterdam.

LOBO, E.A., CALLEGARO, V.L.M., HERMANY, G., BES, D., WETZEL, C.A \& OLIVEIRA, M.A. 2004. Use of epilithic diatoms as bioindicators, with special emphasis to the eutrophication problem of lotic systems in Southern Brazil. Acta Limnol. Bras., 16(1):25-40.

LOBO, E.A. \& LEIGHTON, G. 1986. Estructuras comunitarias de las fitocenosis planctónicas de los sistemas de desembocaduras de rios y esteros de la zona central de Chile. Ver. Biol. Mar. Oceanogr., 22(1):1-29.

MACKERETH, F.J.H., HERON, J. \& TALLING, J.F. 1978. Water Analysis: Some Revised Methods for Limnologists. Freshwater Biological Association, Scientific Publication, p.120.

MARGALEF, R. 1983. Limnologia. Editora Omega, Barcelona.

MCINTIRE, C.D. 1968. Structural Characteristics of Benthic Algal Communities in Laboratory Streams. Ecology, 49:520-537.

MORESCO, C. \& RODRIGUES, L. 2006. Cianobactérias perifíticas nos reservatórios de Segredo e Iraí, Estado do Paraná, Brasil. Acta Sci. Biol. Sci., 28(4):335-345.

MORESCO, C. \& RODRIGUES, L. 2013. O perifiton como bioindicador em rios. In Ecologia do perifiton (A. Schwarzbold, A.L. Burliga \& L.C. Torgan, eds). Rima, São Carlos, p.147-155.

MOSCHINI-CARLOS, V. \& HENRY, R. 1997. Aplicação de índices para a classificação do perifíton em substratos natural e artificial, na zona de desembocadura do rio Paranapanema (Represa de Jurumirim), SP. Ver. Bras. Biol., 57(4):655- 663.
NEIFF, J.J. 1990. Ideas para la interpretacion ecológica del Paraná. Interciencia, 15(6):424- 441

PASSY, S.I. 2007. Diatom ecological guilds display distinct and predictable behavior along nutrient and disturbance gradients in running waters. Aquat. Bot., 86:171-178.

PRESCOTT, G.W. 1982. Algae of de Western great lakes area. Otto Koeltz Science Publishers, Koenigstein.

R Development Core Team. 2014. R: A language and environment for statistical computing. R Foundation for Statistical Computing: Vienna, Austria. Available: http://www.R-project.org/

RODRIGUES, L., ALGARTE, V.M., SIQUEIRA, N.S. \& MACHADO, E.M.N. 2013. Fatores envolvidos na distribuição e abundância do perifíton e principais padrões encontrados em ambientes de planícies de inundação. In Ecologia do perifiton (A. Schwarzbold, A.L. Burliga \& L.C. Torgan, eds). Rima, São Carlos, p.131-147.

RODRIGUES L. \& BICUDO, D.C. 2001. Similarity among periphyton algal communities in a lentic-lotic gradient of the Upper Paraná river floodplain, Brazil. Braz. J. Bot., 24: 235-248.

RODRIGUES, L., BICUDO, D.C. \& MOSCHINI-CARLOS, V. 2003. O papel do perifíton em áreas alagáveis e nos diagnósticos ambientais. In Ecologia e manejo de macrófitas aquáticas (S.M. Thomaz \& L.M. Bini, eds). Eduem, Maringá, p.211-230.

ROS, J. 1979. Práctica de Ecologia. Omega, Barcelona.

ROUND, F.E. 1965. The biology of the algae. Edward Arnold (Publishers) Ltd, London.

ROUND, F.E. 1991. Diatoms in river water-monitoring studies. J. Appl. Phycol., 3:129-145.

ROUND, F.E. 1971. The taxonomy of the Chlorophyta, 2. Brit. phycol. J., 6(2): $235-264$

ROUND, F.E. 2004. pH scaling and diatom distribution. Diatom, 20:9-12.

ROUND, F.E., CRAWFORD, R.M. \& MANN, D.G. 1990. The diatoms biology e morphology of the genera. Cambridge University Press, New York.

RUSANOV, A.G., STANISLAVSKAYA, E.V. \& ÁCS, E. 2009. Distribution of periphytic diatoms in the rivers of the Lake Ladoga basin (Northwestern Russia). Acta Bot. Croat., 68(2):301-312.

SCHNECK, F., SCHWARZBOLD, A., RODRUIGUES, S.C. \& MELO, A.S. 2011. Environmental variability drives phytoplankton assemblage persistence in a subtropical reservoir. Austral Ecol., 36:839-848.

SCHWARZBOLD, A. 1990. Métodos ecológicos aplicados ao estudo do perifíton. Acta Limnol. Brasil., 3: 545-592,

SALOMONI, S.E. \& TORGA, L.C. 2008. Epilithic diatoms as organic contamination degree indicators in Guaíba Lake, Southern Brazil. Acta Limnol. Bras., 20(4):313-324.

SHANNON, C.E. \& WEAVER, W. 1963. The mathematical theory of communication. Illinois University Press, Urbana.

SIMONS, J. 1994. Field ecology of freshwater macroalgae in pools and ditches, with special attention to eutrophication. Neth. J. Aquat. Ecol., 28:25-33.

SOUZA-FILHO, E.E. 2009. Evaluation of the Upper Paraná river discharge controlled by reservoirs. Braz. J. Biol., 69(2, Suppl.): 707-716.

SOUZA-FILHO, E.E, COMUNELlO, E., PETRY, A.C., RUSSO, M.R., SANTOS, A.M., ROCHA, R.R.A. \& LEIMIG, R.A. 2000. Descrição dos locais de amostragem. In A planície alagável do alto rio Paraná: estruturas e processos ambientais (A.A. Agostinho, ed). Relatório técnico anual do Sítio 6/apoio CNPq-PELD, Maringá, Nupélia/PELD, p.62-74.

SOUZA-FILHO, E.E., ZANETTI, K., PECCININI, J.P. \& FRANÇA, V. 2010. A hidroquímica do rio Paraná após a barragem de Porto Primavera. Bol. Geogr., 28(2):101-112.

STATSOFT Inc. (2005) Statistica (data analysis software system). Version 7.1. http://www.statsoft.com 
Periphytic algae under low water conditions

STEVAUX, J.C., MARTINS, D.P. \& MEURER, M. 2009. Changes in regulated tropical rivers: the Paraná river downstream Porto Primavera Dam, Brazil. Geomorphology, 113(3-4):230-238.

STEVENSON, R.J. 1996. An introduction to algae ecology in freshwater benthic habitats. In: Algal ecology: freshwater benthic ecosystems (R.J. Stevenson, M.L. Bothwell \& R.L. Lowe, eds). Academic Press, San Diego, p. 3-30.

STEVENSON, R.J. 1997. Scale-dependent determinants and consequences of benthic algal heterogeneity. J. N. Am. Benthol. Soc., 16:248-262.

TEN CATE, J.H., MAASDAM, R. \& ROIJACKERS, R.M.M. 1993. Perspectives for the use of diatom assemblages in the water management policy of Overijssel (The Netherlands). Hydrobiologia, 269/270:351-359.

THOMAZ, S.M., ROBERTO, M.C. \& BINI, L.M. 1997. Caracterização limnológica dos ambientes aquáticos e influência dos níveis fluviométricos. In A Planície de Inundação do Alto Rio Paraná (A.E.M.A. Vazzoler, A.A. Agostinho \& N.S. Hahn, eds). Eduem, Maringá, p.73-102.

THOMAZ, S.M., BINI, L.M. \& BOZELLI, R.L. 2007. Floods increase similarity among aquatic habitats in river-floodplain systems. Hydrobiologia, 579:1-13.

THOMAZ, S.M., BINI, L.M., PAGIORO, T.A., MURPHY, K.J., SANTOS, A.M. \& SOUZA, D.C. 2004. Aquatic macrophytes: diversity, biomass and decomposition. In The Upper River and its floodplain: physical aspects, ecology and conservation. (S.M. Thomaz, A.A. Agostinho \& N.S. Hahn, eds). Backhuys Publishers, p.331-352.
TREMARIN, P.I., LUDWIG, T.A.V., BERTOLLI, L.M., FARIA, D.M. \& COSTIN, J.C. 2009. Gomphonema Ehrenberg and Gomphosphenia LangeBertalot (Bacillariophyceae) from Maurícioriver, Paraná, Brazil. Biota Neotrop., 9:111-130.

UTERMÖHL, H. 1958. Zur Vervollkommnung der quantitativen PhytoplanktonMethodik. Mitt. Int. Ver. Theor. Angew. Limnol., 9:1-38.

WEHR, J.D. \& SHEAT, R.G. 2003. Freshwater Algae of North America. Ecology and Classification. Academic Press, New York.

WEILHOEFER, C.L. \& PAN, Y. 2006. Diatom-based bioassessment in wetlands: how many samples do we need to characterize the diatom assemblage in a wetland adequately? Wetlands, 26:793-802.

WETZEL, R.G. 1983. Limnology. Saunders College Publishing, Philadelphia.

WOODWARD, G., PERKINS, D. \& BROWN, L. 2010. Climate change and freshwater ecosystems: impacts across multiple levels of organization. Phil. Trans. R. Soc. B., 365:2093-2106.
Received: $13 / 01 / 2016$

Revised: 21/03/2016

Accepted: 14/06/2016 